\title{
PREVALENCE OF INFECTION WITH CAGA- POSITIVE HELICOBACTER PYLORI STRAINS AMONG CHILDREN AND ADOLESCENTS IN SOUTHERN BRAZIL
}

\author{
Juliana Ghisleni de OLIVEIRA ${ }^{1}$, Cristina Helena Targa FERREIRA ${ }^{1,2,3}$, \\ Anna Carolina Saraiva CAMERIN ${ }^{4}$, Cláudia Augustin ROTA ${ }^{1}$, \\ Luíse MEURER ${ }^{5}$ and Themis Reverbel da SILVEIRA ${ }^{1}$
}

\begin{abstract}
Context - Helicobacter pylori (H. pylori) has a worldwide distribution, but the prevalence of infection, virulence factors, and clinical presentation vary widely according to the studied population. In Brazil, a continental country composed of several ethnicities and cultural habits, the behavior of infection also appears to vary, as many other studies have shown. Objective - Describe the prevalence of infection with cagA-positive H. pylori strains in a group of children and adolescents who underwent esophagogastroduodenoscopy in Porto Alegre, Rio Grande do Sul. Methods - Fifty-four gastric biopsy specimens of children and adolescents with $\mathrm{H}$. pylori infection demonstrated by histology, urease test and molecular analysis were tested for the presence of $\operatorname{cag} A$-positive H. pylori strains by the polymerase chain reaction method. Results - The prevalence of cagA-positive H. pylori was $29.6 \%(95 \%$ confidence interval, 18 to $43.6 \%$ ). There were no statistically significant differences in clinical or demographic characteristics or in the endoscopic and histological features of patients infected with $c a g A$-positive strains as compared with those infected by $c a g A$-negative strains. Conclusions - The study showed a low prevalence of infection with cagA-positive H. pylori strains among children and adolescents who underwent EGD in southern Brazil, in comparison to studies conducted with children from other regions of Brazil. There was no association between the presence of $\operatorname{cag} A$-positive strains and more severe clinical presentations in the studied sample. HEADINGS - Helicobacter pylori. Helicobacter infections, genetics. Prevalence. Child.
\end{abstract}

\section{INTRODUCTION}

Helicobacter pylori (H. pylori) is one of the commonest pathogens in humans, affecting more than $50 \%$ of the world's population ${ }^{(31)}$. Although infection rates are decreasing in pediatric populations from different regions, with prevalence ranging from less than $10 \%$ to $28 \%(16,17,18,21,27), H$. pylori still plays an important role in the pathogenesis of peptic ulcer disease, gastric adenocarcinoma and gastric mucosaassociated lymphoid tissue lymphoma ${ }^{(2)}$ - diseases that carry high morbidity and mortality rates. $H$. pylori infection is acquired predominantly in childhood $^{(18,31)}$. Once the gastric mucosa is colonized, the bacterium is likely to remain there for decades, if not throughout the life of the host ${ }^{(34)}$. However, the vast majority of infected individuals remain asymptomatic $^{(14)}$. The wide spectrum of clinical manifestations is determined by the interaction of the host's own immune factors with environmental factors, as well as by the prevalence and expression of $H$. pylori virulence factors ${ }^{(32)}$.

The most widely studied of these factors is cytotoxin-associated gene A ( $\operatorname{cagA}$ ), one of the component genes of the "cag pathogenicity island" (cag-PAI) and a marker of its presence ${ }^{(33)}$. This gene encodes the CagA protein, which induces secretion of inflammatory cytokines, particularly interleukin- 8 (IL-8), a potent chemotactic factor and activator of polymorphonuclear leukocytes and macrophages; this ultimately leads to a marked inflammatory response in the host ${ }^{(33)}$. However, the presence of

Declared conflict of interest of all authors: none

Source of Funding: This work was supported by National Counsel of Technological and Scientific Development (CNPq) and the Incentive Fund Research (FIPE) from Hospital de Clínicas de Porto Alegre.

${ }^{1}$ Programa de Pós Graduação em Saúde da Criança e do Adolescente, Faculdade de Medicina, Universidade Federal do Rio Grande do Sul - UFRGS; ${ }^{2}$ Unidade de Gastroenterologia Pediátrica, Hospital de Clínicas de Porto Alegre; ${ }^{3}$ Unidade de Endoscopia Digestiva, Hospital Moinhos de Vento, Porto Alegre; ${ }^{4}$ Laboratório Amplicon, Porto Alegre. ${ }^{5}$ Departamento de Patologia, Hospital de Clínicas de Porto Alegre e Medicina Digital. RS, Brasil.

Correspondence: Juliana Ghisleni de Oliveira. Rua São Luís, 920, 603, Santana - CEP 90620-170 - Porto Alegre, RS, Brasil. E-mail: jughisleni@terra.com.br 
cagA-positive strains is not the sole predictor of clinical outcomes ${ }^{(33)}$. The $\operatorname{cag} \mathrm{A}$ gene is diverse in its structure, especially at the 3'-terminal region, which bears a variable sequence of amino acid repetitions. This contributes to the understanding of the variety in clinical presentations observed between different individuals colonized by cagApositive strains ${ }^{(20,33)}$.

H. pylori is ubiquitous worldwide, but the prevalence of infection and the presence of virulence factors are highly variable according to the studied population, as is the clinical presentation of $H$. pylori infection ${ }^{(15,34)}$. In Brazil, a continental country composed of diverse ethnicities and cultural habits, the behavior of $H$. pylori infection also appears to vary, as various studies have demonstrated ${ }^{(8,29)}$. So far, no published studies have used molecular analysis methods to assess $H$. pylori virulence factors in children from southern Brazil. The aim is to describe the prevalence of infection with cagA-positive strains of $H$. pylori in a group of children and adolescents who underwent esophagogastroduodenoscopy (EGD) in Porto Alegre, a city in Southern Brazil.

\section{METHODS}

\section{Patients}

This cross-sectional study was conducted from March 2008 to January 2011 on a sample of 400 children and adolescents with gastrointestinal symptoms who underwent EGD at Hospital de Clínicas de Porto Alegre and Hospital Moinhos de Vento, both located in Porto Alegre, a large city in Southern Brazil. The inclusion criteria were age between 1 and 18 years, endoscopic nodular gastritis (which is associated with the presence of bacteria in children ${ }^{(3,18)}$, and/or peptic ulcer and/or a positive urease test and/or presence of $H$. pylori on histological analysis. Patients with any contraindications to biopsy, those with a history of use of antibiotics, proton pump inhibitors, bismuth salts, or $\mathrm{H}_{2}$ blockers in the month preceding from the procedure, and those with history of non-steroidal anti-inflammatory drug and/or acetylsalicylic acid use for three days prior to the procedure were excluded from the study.

\section{Ethical considerations}

Subjects' parents or legal guardians were instructed about the study, and written informed consent was obtained. A questionnaire designed to collect demographic and clinical data was administered to each participant. The study was approved by the Ethics Committees of both centers where it was performed.

\section{Endoscopy}

All endoscopies were performed by the same physician (CHTF). The main endoscopic findings were recorded descriptively ${ }^{(10)}$. Five biopsy specimens were for histological evaluation (two from the body, two from the antrum, and one from the angular incisure) according to Sydney System recommendations ${ }^{(9)}$. In addition, four biopsy specimens (two from the body and two from the antrum, one from each segment) were collected for rapid urease testing and molecular analysis respectively, in order to reduce sampling error $^{(18)}$.

\section{Histological analysis}

The biopsy specimens were fixed in formalin, dehydrated, and embedded in paraffin wax. Sections measuring $4 \mu \mathrm{m}$ were sliced and stained with hematoxylin-eosin (for grading of gastritis severity) or with the Giemsa stain (to detect $H$. pylori) per standard procedures. The classification and grading of gastritis were made in accordance with the modified Sydney system ${ }^{(9)}$. All analyses were performed by the same pathologist, who had no knowledge of the results of other tests (LM).

\section{Rapid trease test}

The rapid urease test was performed using one biopsy specimen from the body and one from the gastric antrum, which were placed into a commercially available solution containing $10 \%$ urea, $1 \mathrm{~mL}$ buffered potassium phosphate, and a $\mathrm{pH}$ indicator $\left(\right.$ Uretest $^{\circledR}$, Renylab Ltda., Minas Gerais, Brazil), at room temperature. Results were recorded up to 12 hours after inoculation. A change of color from yellow to pink was recorded as a positive reaction.

\section{H. pylori and cagA gene detection by polymerase chain reaction (PCR)}

The biopsy specimens set aside for molecular analysis (one from the body and one from the antrum) were placed in isotonic saline $(0.9 \% \mathrm{NaCl}$ solution) and deoxyribonucleic acid (DNA) was isolated directly from the specimens using the QIAamp tissue kit (Qiagen Inc., Santa Clarita, CA, USA), according to manufacturer instructions.

PCR primer sets specific for $H$. pylori $16 \mathrm{~S}$ rRNA and the ure $A$ gene, previously tested in an adult sample of our population, with good sensitivity and specificity ${ }^{(26)}$, were used. The CagA/ConF (5'-GTGCCTGCTAGTTTGTCAGCG-3') and CagA/ConR (5'-TTGGAAACCACCTTTTGTATTAGC-3') forward and reverse primers were used for detection of the cagA gene. The final product of the $16 \mathrm{~S}$ rRNA reaction was examined by electrophoresis on 3\% agarose gel. The ureA, CagA/ConF e CagA/ConR amplimers were examined by electrophoresis on $2 \%$ agarose gels. Results were considered positive when products with molecular weights equivalent to those previously determined were found. Negative and positive controls were included in each assay.

\section{Statistical analysis}

Categorical and continuous variables were described as percentages and mean \pm standard deviation (SD) respectively. The chi-square and Fisher's exact tests were used as appropriate for comparisons between categorical variables. Comparisons between quantitative variables were performed using the Student $t$ test. The significance level $(\alpha)$ was set at 0.05 . Data were analyzed in the SPSS 17.0 software package (SPSS Inc., Chicago, IL, USA). 


\section{RESULTS}

Ninety-eight subjects was included in the study. H. pylori was identified through molecular analysis in 54 subjects, whose specimens were therefore tested for presence of the cagA gene.

The clinical and demographic characteristics of these 54 patients are shown in Table 1.

TABLE 1. Characteristics of 54 subjects positive for $H$. pylori (PCR)

\begin{tabular}{|c|c|}
\hline Parameter & Finding \\
\hline Age* & $9.8 \pm 4.4(1.8-18.5)$ \\
\hline \multicolumn{2}{|l|}{ Gender $\dagger$} \\
\hline Male & $27(50)$ \\
\hline Female & $27(50)$ \\
\hline \multicolumn{2}{|l|}{ EGD indication $\dagger$} \\
\hline Abdominal pain & $18(34.6)$ \\
\hline Vomiting/GERD & $13(24.9)$ \\
\hline Investigation of malabsorption & $11(21.2)$ \\
\hline Gastrointestinal bleeding & $7(13.4)$ \\
\hline Others & $5(5.9)$ \\
\hline \multicolumn{2}{|l|}{ Water supply $\dagger$} \\
\hline Mains & $47(94)$ \\
\hline Other & $3(6)$ \\
\hline \multicolumn{2}{|l|}{ Sewage system $\dagger$} \\
\hline Yes & $47(94)$ \\
\hline No & $3(6)$ \\
\hline \multicolumn{2}{|l|}{ Maternal education $\dagger$} \\
\hline$\leq 8$ years & $29(60)$ \\
\hline $9-11$ years & $14(29)$ \\
\hline$>11$ years & $5(11)$ \\
\hline \multicolumn{2}{|l|}{ Paternal education $\dagger$} \\
\hline$\leq 8$ years & $33(72)$ \\
\hline $9-11$ years & $7(15)$ \\
\hline$>11$ years & $6(13)$ \\
\hline \multicolumn{2}{|l|}{ People per room of household $\dagger \neq$} \\
\hline$\leq 0.5$ & $4(8)$ \\
\hline $0.5-0.99$ & $17(35)$ \\
\hline $1-1.99$ & $24(49)$ \\
\hline$\geq 2$ & $4(8)$ \\
\hline \multicolumn{2}{|c|}{ Family history of peptic ulcer disease $\dagger$} \\
\hline Yes & $15(29)$ \\
\hline No & $37(71)$ \\
\hline \multicolumn{2}{|l|}{ Family history of stomach cancer $\dagger$} \\
\hline Yes & $10(19)$ \\
\hline No & $42(81)$ \\
\hline
\end{tabular}

EGD: esophagogastroduodenoscopy; GERD: gastroesophageal reflux disease; PCR: polymerase chain reaction.

* Mean \pm standard deviation (range); ${ }^{\dagger}$ Frequency observed (\%, percentage of valid findings);

$\ddagger$ Not counting bathrooms. After Staat et al. ${ }^{(30)}$.
The prevalence of infection with cagA-positive $H$. pylori strains in the sample was $29.6 \%$ (16 of 54 subjects, $95 \%$ confidence interval, $18 \%-43.6 \%$ ). There were no statistically significant differences in demographic and clinical characteristics between patients infected with cagA-positive strains and those infected with $\operatorname{cagA}$-negative strains. Patients with cagA-positive $H$. pylori infection were more likely to have a family history of peptic ulcer disease $(P=0.04)$. Stratification of patients into three age groups ( 1 to 4 years, 5 to 10 years, and $\geq 10$ years) failed to reveal any significant increase in cag A positivity with increasing age $(P$ trend $=0.43)$.

Endoscopic nodular gastritis and follicular lymphoid hyperplasia were not different between the infected individuals by cagA-positive and cagA-negative $H$. pylori strains $(63 \%$ versus $50 \%$ and $63 \%$ versus $39 \% ; P=0.59$ and $P=0.21$ ). Duodenal ulcer was identified in one of the 54 subjects, who was colonized with a cagA-negative strain. By histological analysis, no between-group differences in bacterial density and inflammatory activity were found. Gastric atrophy was observed in two subjects, both of whom were infected with cagA-negative strains. The main endoscopic and histological findings of this sample of patients are shown in Table 2.

TABLE 2. Main endoscopy and histology findings of patients infected with cagA-positive and cagA-negative $H$. pylori strains $(\mathrm{n}=54)$

\begin{tabular}{|c|c|c|c|}
\hline & $\operatorname{cagAs}$ & tatus & \\
\hline & $\begin{array}{c}\text { Negative }(\mathrm{n}=38) \\
\mathrm{n}(\% \text { valid })\end{array}$ & $\begin{array}{c}\text { Positive }(\mathrm{n}=6) \\
\mathrm{n}(\% \text { valid })\end{array}$ & $P$-value \\
\hline Endoscopic finding & & & $*$ \\
\hline Normal & $5(13)$ & $5(31)$ & 0.14 \\
\hline Gastritis nodular & $19(50)$ & $10(63)$ & 0.59 \\
\hline Other gastritis & $12(32)$ & $2(13)$ & 0.19 \\
\hline Duodenal ulcer & 1 & 0 & $\mathrm{NR} *$ \\
\hline Histologic finding & & & \\
\hline Gastritis classification & & & 0.89 \\
\hline Mild & $17(45)$ & $6(38)$ & \\
\hline Moderate & $19(50)$ & $9(56)$ & \\
\hline Marked & $2(5)$ & $1(6)$ & \\
\hline Activity & & & 0.78 \\
\hline Mild & $23(61)$ & $9(56)$ & \\
\hline Moderate & $13(34)$ & $7(44)$ & \\
\hline Marked & $2(5)$ & 0 & \\
\hline H. pylori density & & & 0.89 \\
\hline Mild & $5(14)$ & $3(19)$ & \\
\hline Moderate & $27(75)$ & $11(69)$ & \\
\hline Marked & $4(11)$ & $2(12)$ & \\
\hline Lymphoid hyperplasia & & & 0.21 \\
\hline Yes & $15(39)$ & $10(63)$ & \\
\hline Intestinal metaplasia & & & $*$ \\
\hline Yes & 0 & 0 & \\
\hline Atrophy & & & $*$ \\
\hline Yes & 2 & 0 & \\
\hline
\end{tabular}

Not performed due small number of observations 


\section{DISCUSSION}

The present study revealed a lower prevalence of cagApositive $H$. pylori infection in children and adolescents from southern Brazil compared to the prevalence described in other Brazilian regions, where the frequency of these strains ranged from $67 \%$ to $78 \%$ in different studies (see Table 3$)^{(1,6,12,23)}$. It is worth noting that some limitations hamper comparison between these studies, given the wide heterogeneity of demographic and clinical characteristics in their samples and the variety of diagnostic methods employed. However, the highest prevalence of cagA-positive strains infection (78\%) was found in a study that included asymptomatic children, who were evaluated by enzyme-linked immunosorbent assay for presence of the cagA gene ${ }^{(6)}$. Although this result may not be comparable to our study from a methodological viewpoint, as circulating antibodies can be present for a long time even after spontaneous eradication of infection ${ }^{(23)}$, this makes our results even more relevant, since our study only included patients with gastrointestinal complaints. Even with no proven association between the presence of H. pylori infection and any specific symptom ${ }^{(18)}$, one could expect to find a higher prevalence of cagA-positive strains than we actually did $(29.6 \%)$ considering that patients in our sample had more severe clinical presentations ${ }^{(11)}$. Previous studies with adults from southern Brazil, including from southern Brazil, including from Porto Alegre, found prevalence rates of cagA-positive infection ranging from $65 \%$ to $71 \%{ }^{(24,26)}$, as well as an association between presence of this gene and duodenal ulcer ${ }^{(26)}$ and gastric cancer ${ }^{(19)}$. The difference between adults and children from the same population may denote a different behavior of the infection in children ${ }^{(18,20,31)}$.
Colonization by cagA-positive strains seems to increase with age ${ }^{(23)}$, although we did not confirm this finding in our study. Queiroz et al. ${ }^{(23)}$ argue that the susceptibility of children to colonization by cagA-positive strains may be related to differences in the expression of adhesion molecules in the gastric mucosa, which changes over time. Sgouras et al. ${ }^{(28)}$ noted that children actually tend to have a higher prevalence of cagA-negative strains than adults, and believe this is a mechanism used by bacteria to allow successful colonization, as these strains induce a weaker host inflammatory response. Another aspect discussed by Cover and Blaser ${ }^{(7)}$ concern changes in the predominant strain type in some populations. People in developing countries are predominantly colonized by cagA-positive strains, whereas those in many developed countries are colonized in almost equal proportion by cagApositive and cagA-negative strains ${ }^{(7)}$. Positive strains used to be more susceptible to antibiotic eradication, which may explain these differences ${ }^{(7)}$.

The methods employed in this study can also help understand our findings. DNA extraction from isolates obtained from multiple colonies of $H$. pylori grown in culture can theoretically lead to different results compared to a technique that performs extraction directly from gastric biopsy specimens $^{(22)}$, as the one employed in our study. In two of the four Brazilian studies $^{(1,23)}$ assessing cagA-positive H. pylori strains in children, molecular analysis of isolates was obtained by culture, which could explain the lower prevalence observed in our population. Direct PCR from biopsy specimens tends to underestimate the prevalence of a specific virulence factor such as cagA, especially when bacterial density is low ${ }^{(22)}$. Infection with multiple $H$. pylori strains can also interfere with the sensitivity of the method, and even though deliberate search for other virulence factors was not performed in our

TABLE 3. Prevalence of cagA-positive strains in Brazilian children

\begin{tabular}{|c|c|c|c|}
\hline $\begin{array}{l}\text { Author, year } \\
\text { Place of study }\end{array}$ & Genotyping method & $\begin{array}{c}\text { Prevalence }(\%) \mathrm{n} / \\
\text { total } \\
95 \% \mathrm{CI}\end{array}$ & $\begin{array}{l}\text { Clinical presentation ( } \mathrm{n} \text { ) } \\
\text { and cagA gene }\end{array}$ \\
\hline
\end{tabular}

Queiroz et al. ${ }^{(23)}, 2000$

Belo Horizonte, Minas Gerais

PCR from isolates obtained by culture

PCR from isolates obtained by culture

$38 / 55(69)$

Ashour et al. ${ }^{(1)}, 2002$

Belo Horizonte, Minas Gerais

Gatti et al. ${ }^{(12)}, 2006$

Marília, São Paulo

Cartágenes et al. ${ }^{(6)}, 2009$

Belém, Pará

Antibody anti-cagA by ELISA method
$60 / 80(75)$

64-81
Duodenal ulcer (27)

100\% cagA-positive

Our study

Direct PCR of gastric biopsy specimen

Duodenal ulcer (24)

94.7\% cagA-positive

Chronic gastritis (29)

$69 \%$ cagA-positive

$\begin{array}{cc}38 / 57(67) & \text { Chronic gastritis (29) } \\ 53-79 & 69 \% \text { cagA-positive }\end{array}$

$39 / 50(78)$

64-89
Not described 
study, this possibility cannot be ruled out ${ }^{(22)}$. Partial deletion of PAI could also yield cagA-negative results ${ }^{(14,22)}$.

In the international literature, prevalence rates similar to ours were reported in pediatric patients in Jordan and Israel, with a cagA-positive strain prevalence of 26.4 and $25.5 \%$ respectively ${ }^{(5,15)}$. Positive strains were not associated with more pronounced histological gastritis or duodenal ulcer in these studies ${ }^{(5,15)}$; this is consistent with our findings, but goes against what has been described elsewhere in the literature ${ }^{(1,12,23)}$.

No one particular $H$. pylori virulence factor can be the sole determinant of clinical presentation, which is the result of interactions between the predominant strain type, the host, and the environment in which they live ${ }^{(5)}$. Several authors $^{(4,20,28)}$ argue that cagA polymorphisms may affect its biological function, justifying the lack of association between the presence of the gene and a more severe clinical presentation, as was observed in this and other studies ${ }^{(13,20,28)}$. Furthermore, the mere presence of a gene does not suffice; it must be expressed in the host for its role in pathogenesis to be fully evaluated ${ }^{(25)}$.

Finally, the clinical heterogeneity of our sample, which included patients with various gastrointestinal symptoms and over a wide age range, can be considered a major limitation of this study. The low prevalence of cagA-positive strains and low overall prevalence of $H$. pylori-related diseases observed in our sample may account for the lack of clinical association between the presence of these strains and more severe chronic gastritis and duodenal ulcer.

In conclusion, this study found a low prevalence of infection with cagA-positive $H$. pylori strains in children and adolescents who underwent EGD in Southern Brazil. No association between colonization with cagA-positive strains and severe clinical outcomes was observed in this sample.

Oliveira JG, Ferreira CHT, Camerin ACS, Rota CA, Meurer L, Silveira TR. Prevalência da infecção por cepas de Helicobacter pylori cagA-positivo em crianças e adolescentes do Sul do Brasil. Arq Gastroenterol. 2014,51(3):180-5.

RESUMO - Contexto - Helicobacter pylori (H. pylori) tem distribuição geográfica universal, embora a prevalência da infecção, os fatores de virulência, bem como a apresentação clínica, variem de acordo com a população estudada. No Brasil, um país continental composto por várias etnias e hábitos culturais diversos, o comportamento da infecção também parece variar, como muitos estudos têm demonstrado. Objetivo - Descrever a prevalência da infecção por cepas de H. pylori cagA-positivo em um grupo de crianças e adolescentes submetidos a esofagogastroduodenoscopia em Porto Alegre, Rio Grande do Sul. Métodos - Cinquenta e quatro (54) fragmentos de biópsia gástrica com presença de H. pylori demonstrada pela análise histológica, teste da urease e análise molecular foram testados para a presença de cepas de $H$. pylori cagA-positivo pelo método da reação em cadeia da polimerase. Resultados - A prevalência de cepas de H. pylori cagA-positivo foi de 29,6\% (intervalo de confiança de 95\%, 18\% a 43,6\%). Não houve diferenças estatisticamente significativas nas características clínicas e demográficas e nos achados endoscópicos e histológicos entre os pacientes infectados por cepas de H. pylori cagA-positivo em comparação com os cagA-negativo. Conclusões - O estudo demonstrou uma baixa prevalência de infecção por cepas de H. pylori cagA-positivo nas crianças e adolescentes submetidas a esofagogastroduodenoscopia no Sul do Brasil em comparação com os estudos realizados com crianças de outras regiões do Brasil. Não houve associação entre a presença de cepas cagA-positivo e desfechos clínicos desfavoráveis na amostra estudada.

DESCRITORES - Helicobacter pylori. Infecções por Helicobacter, genética. Prevalência. Criança. 


\section{REFERENCES}

1. Ashour AA, Gusmão VR, Magalhães PP, Mendes EN, Queiroz DMM, Rocha GA, et al. VacA alleles, cagA, and duodenal ulcer in children in Brazil. J Bras Patol Med Lab. 2002;38:79-85.

2. Atherton JC, Blaser MJ. Coadaptation of Helicobacter pylori and humans: ancient history, modern implications. J Clin Invest. 2009;119:2475-87.

3. Bahú Mda G, da Silveira TR, Maguilnick I, Ulbrich-Kulczynski J. Endoscopic nodular gastritis: an endoscopic indicator of high-grade bacterial colonization and severe gastritis in children with Helicobacter pylori. J Pediatr Gastroenterol Nutr. 2003;36:217-22.

4. Batista SA, Rocha GA, Rocha AM, Saraiva IE, Cabral MM, Oliveira RC, Queiroz DM. Higher number of Helicobacter pylori CagA EPIYA C phosphorylation sites increases the risk of gastric cancer, but not duodenal ulcer. BMC Microbiol. 2011;11:61.

5. Benenson S, Halle D, Rudensky B, Faber J, Schlesinger Y, Branski D, et al. Helicobacter pylori genotypes in Israeli children: the significance of geography. J Pediatr Gastroenterol Nutr. 2002;35:680-4

6. Cartágenes VD, Martins LC, Carneiro LM, Barile KA, Corvelo TC. Helicobacter pylori in children and association with CagA strains in mother-child transmission in the Brazilian Amazon region. Rev Soc Bras Med Trop. 2009;42:298-302.

7. Cover TL, Blaser MJ. Helicobacter pylori in health and disease. Gastroenterology. 2009;136:1863-73.

8. Dattoli VC, Veiga RV, da Cunha SS, Pontes-de Carvalho LC, Barreto ML, Alcântara-Neves NM. Seroprevalence and potential risk factors for Helicobacter pylori infection in Brazilian children. Helicobacter. 2010;15:273-8.

9. Dixon MF, Genta RM, Yardley JH, Correa P. Classification and grading of gastritis. The updated Sydney System. International Workshop on the Histopathology of Gastritis, Houston 1994. Am J Surg Pathol. 1996;20:1161-81.

10. Dohil R, Hassall E, Jevon G, Dimmick J. Gastritis and gastropathy of childhood. J Pediatr Gastroenterol Nutr. 1999;29:378-94

11. Elitsur Y, Neace C, Werthammer MC, Triest WE. Prevalence of CagA, VacA antibodies in symptomatic and asymptomatic children with Helicobacter pylori infection. Helicobacter. 1999;4:100-5.

12. Gatti LL, de Lábio R, Silva LC, Smith MAC, Payão SLM. CagA positive Helicobacter pylori in Brazilian Children Related to Chronic Gastritis. Braz J Infect Dis. 2006;10:254-8.

13. Gold BD, van Doorn LJ, Guarner J, Owens M, Pierce-Smith D, Song Q, et al. Genotypic, clinical, and demographic characteristics of children infected with Helicobacter pylori. J Clin Microbiol. 2001;39:1348-52.

14. Hsu PI, Hwang IR, Cittelly D, Lai KH, Gutierrez O, Kim JG, et al. Clinical presentation in relation to diversity within the Helicobacter pylori cag pathogenicity island. Am J Gastroenterol. 2002;97:2231-8.

15. Hussein NR. Helicobacter pylori and gastric cancer in the Middle East: a new enigma? World J Gastroenterol. 2010;16:3226-34.

16. Janjetic MA, Goldman CG, Barrado DA, Cueto Rua E, Balcarce N, Mantero P, et al. Decreasing trend of Helicobacter pylori infection in children with gastrointestinal symptoms from Buenos Aires, Argentina. Helicobacter. 2011;16:316-9.

17. Kawakami E, Machado RS, Ogata SK, Langner M. Decrease in prevalence of Helicobacter pylori infection during a 10-year period in Brazilian children. Arq Gastroenterol. 2008;45:147-51.
18. Koletzko S, Jones NL, Goodman KJ, Gold B, Rowland M, Cadranel S, et al. Evidence-based guidelines from ESPGHAN and NASPGHAN for Helicobacter pylori infection in children. J Pediatr Gastroenterol Nutr. 2011;53:230-43.

19. Meine GC, Rota C, Dietz J, Sekine S, Prolla JC. Relationship between cagA-positive Helicobacter pylori infection and risk of gastric cancer: a case control study in Porto Alegre, RS, Brazil. Arq Gastroenterol. 2011;48:41-5.

20. Mohamed R, Hanafiah A, Rose IM, Manaf MR, Abdullah SA, Sagap I, et al. Helicobacter pylori cagA gene variants in Malaysians of different ethnicity. Eur J Clin Microbiol Infect Dis. 2009;28:865-9.

21. Oona M, Utt M, Nilsson I, Uibo O, Maaroos HI. Helicobacter pylori infection in children in Estonia: decreasing seroprevalence during the 11-year period of profound socioeconomic changes. Helicobacter. 2004;9:233-41.

22. Park CY, Kwak M, Gutierrez O, Graham DY, Yamaoka Y. Comparison of genotyping Helicobacter pylori directly from biopsy specimens and genotyping from bacterial cultures. J Clin Microbiol. 2003;41:3336-8.

23. Queiroz DM, Mendes EN, Carvalho AS, Rocha GA, Oliveira AM, Soares TF, et al. Factors associated with Helicobacter pylori infection by a cagA-positive strain in children. J Infect Dis. 2000;181:626-30.

24. Ramis IB, Fonseca TL, de Moraes EP, Fernandes MS, Mendoza-Sassi R, Rodrigues $\mathrm{O}$, et al. Molecular Basis of pathogenicity in Helicobacter pylori clinical isolates. J Clin Microbiol. 2010;48:3776-8.

25. Rick JR, Goldman M, Semino-Mora C, Liu H, Olsen C, Rueda-Pedraza E, et al. In situ expression of cagA and risk of gastroduodenal disease in Helicobacter pylori-infected children. J Pediatr Gastroenterol Nutr. 2010;50:167-72.

26. Rota CA, Pereira-Lima JC, Blaya C, Nardi NB. Consensus and variable region PCR analysis of Helicobacter pylori 3' region of cagA gene in isolates from individuals with or without peptic ulcer. J Clin Microbiol. 2001;39:606-12.

27. Rothenbacher D, Schultze V, Jähnig P, Scharschmidt B, Brenner H. Evidence of a rapid decrease in prevalence of Helicobacter pylori infection in children of a high risk group living in Germany. Eur J Pediatr. 2004;163:339-40.

28. Sgouras DN, Panayotopoulou EG, Papadakos K, Martinez-Gonzalez B, Roumbani A, Panayiotou J, et al. CagA and VacA polymorphisms do not correlate with severity of histopathological lesions in Helicobacter pylori-infected Greek children. J Clin Microbiol. 2009;47:2426-34.

29. Souto FJ, Fontes CJ, Rocha GA, de Oliveira AM, Mendes EN, Queiroz DM. Prevalence of Helicobacter pylori infection in a rural area of the state of Mato Grosso, Brazil. Mem Inst Oswaldo Cruz. 1998;93:171-4.

30. Staat MA, Kruszon-Moran D, McQuillan GM, Kaslow RA. A population-based serologic survey of Helicobacter pylori infection in children and adolescents in the United States. J Infect Dis. 1996;174:1120-3.

31. Talarico S, Gold BD, Fero J, Thompson DT, Guarner J, Czinn S, Salama NR Pediatric Helicobacter pylori isolates display distinct gene coding capacities and virulence gene marker profiles. J Clin Microbiol. 2009;47:1680-8.

32. Tomb JF, White O, Kerlavage AR, Clayton RA, Sutton GG, Fleischmann RD, et al. The complete genome sequence of the gastric pathogen Helicobacter pylori. Nature. 1997;388:539-47.

33. Yamaoka Y. Mechanisms of disease: Helicobacter pylori virulence factors. Nat Rev Gastroenterol Hepatol. 2010;7:629-41.

34. Yamaoka Y, Reddy R, Graham DY. Helicobacter pylori virulence factor genotypes in children in the United States: clues about genotype and outcome relationships. J Clin Microbiol. 2010;48:2550-1. 